\title{
勈 New Disease Reports \\ First report of Sclerotinia stem and twig blight caused by Sclerotinia sclerotiorum on sour orange rootstock in Turkey
}

\author{
F. Baysal-Gurel ${ }^{1 *}$, Orhan Bozan ${ }^{2}$, Nuket Onelge ${ }^{2}$ and A. Cinar ${ }^{2}$ \\ ${ }^{1}$ Department of Plant Pathology, Ohio Agricultural Research Development Center, The Ohio State University, Wooster, OH \\ 44691, USA; ${ }^{2}$ Department of Plant Protection, Faculty of Agriculture, Cukurova University, Balcalı, Adana-Turkey 01330
}

*E-mail: gurel.2@osu.edu

Received: 31 May 2012. Published: 01 Dec 2012. Keywords: Citrus aurantium, fungal plant disease, nursery seedling production

Sour orange (Citrus aurantium, Rutaceae) is the most commonly used rootstock in citrus (nursery) production in the whole Mediterranean region, although the threat of Citrus tristeza closterovirus is a great concern. In winter 2005, symptoms of Sclerotinia stem and twig blight were observed on 8-month-old sour orange seedlings grown in a greenhouse of a commercial nursery near Adana, Turkey. Seedlings with symptoms of Sclerotinia stem and leaf blight were found with an average disease prevalence of $15 \%$ amongst 10,000 8-month-old C. aurantium seedlings. Initial symptoms included brown lesions on the stem and twigs. As stem and twig lesions progressed, gum exudates appeared and infected seedlings died. Superficial cottony, white mycelium developed and black, irregular-shaped sclerotia $(1.2-4.8 \times 1.0-6.5 \mathrm{~mm}$, average $2.3 \times 3.2 \mathrm{~mm})$ formed externally on the affected stems. Symptom-bearing tissue from 15 seedlings was excised from the edge of the diseased area, surface-sterilised and then placed on potato dextrose agar (PDA). The fungus produced aerial mycelium, which was hyaline, branched, well developed and appeared cottony, consisting of septate hyphae. Sclerotia produced on PDA measured 1.3-4.2 × 1.2-7.0 mm (average $2.6 \times 3.4 \mathrm{~mm}$ ). After a conditioning process of sclerotia, carpogenic germination started and brown coloured apothecia began to form. The asci were hyaline and cylindrical in shape, measuring 121-158 x 6.5-9.5 $\mu \mathrm{m}$ in size. Based on morphological criteria the isolated fungus was determined as Sclerotinia sclerotiorum (Lib.) de Bary (Willets \& Wong, 1980).

To conduct pathogenicity tests, sclerotia produced on carrot discs (Huang \& Kozub, 1989) were surface-sterilised and dried in a laminar flow hood overnight. Ten sclerotia were placed in petri dishes containing $10 \mathrm{ml}$ of sterile distilled water. The dishes were sealed with Parafilm and incubated at $4^{\circ} \mathrm{C}$ for 6 weeks in the dark. They were then incubated at $16^{\circ} \mathrm{C}\left( \pm 2^{\circ} \mathrm{C}\right)$ in $10 \mathrm{~h}$ of darkness and $14 \mathrm{~h}$ of light. Apothecia developed after two weeks. Ascospores were obtained by aseptically detaching apothecia from sclerotia and shaking the apothecia in sterile distilled water in $1.5 \mathrm{~m}$ microcentrifuge tubes. Five-month-old sour orange seedlings were inoculated with ascospores $\left(4 \times 10^{5}\right.$ spores $\left./ \mathrm{ml}\right)$. Inoculated seedlings were enclosed in plastic bags for seven days and incubated at $25 \pm 2^{\circ} \mathrm{C}$ with a $12 \mathrm{~h}$ photoperiod. Seedlings sprayed with sterile distilled water served as controls. All inoculated seedlings developed lesions within 10-14 days, followed by the appearance of white mycelium and sclerotia on the stems. Seedlings often died within four to five weeks after inoculation. Inoculated sour orange seedlings developed symptoms similar to those originally observed in the nursery. Control seedlings remained symptomless. $S$. sclerotiorum was re-isolated from the stems of inoculated seedlings and identified morphologically as previously described.

S. sclerotiorum has been reported as a pathogen on C. volkameriana rootstock in Italy (Polizzi et al., 2011) and on C. unshiu in Korea (Song \& Koh, 1999). To our knowledge, this is the first report of stem and twig blight caused by $S$. sclerotiorum on $C$. aurantium. Because of the importance of sour orange as a rootstock this finding is of relevance for the whole citrus industry, especially for nursery seedling production.

\section{References}

Huang HC, Kozub GC, 1989. A simple method for production of apothecia from sclerotia of Sclerotinia sclerotiorum. Plant Protection Bulletin 31, 333-345.

Polizzi G, Aiello D, Scuderi G, Cirvilleri G, 2011. First report of Sclerotinia stem and twig blight caused by Sclerotinia sclerotiorum on Citrus volkameriana rootstock in Italy. Plant Disease 95, 1030. [http://dx.doi.org/10.1094/PDIS-05-11-0367]

Song JH, Koh YJ, 1999. Sclerotinia twig blight on trees and cottony rot on fruits of Satsuma mandarin caused by Sclerotinia sclerotiorum. Plant Pathology Journal 15, 236-241.

Willetts HJ, Wong JAL, 1980. The biology of Sclerotinia sclerotiorum, S. trifoliorum, and S. minor with emphasis on specific nomenclature. The Botanical Review 46, 101-165. [http://dx.doi.org/10.1007/BF02860868]

To cite this report: Baysal-Gurel F, Bozan O, Onelge N, Cinar A, 2012. First report of Sclerotinia stem and twig blight caused by Sclerotinia sclerotiorum on sour orange rootstock in Turkey. New Disease Reports 26, 24. [http://dx.doi.org/10.5197/j.2044-0588.2012.026.024] 